Jurnal Ilmu Ilmu Agribisnis: Journal of Agribusiness Science, 9(2), Mei 2021

\title{
SISTEM AGRIBISNIS TANAMAN HIAS BUNGA (Adenium, Anggrek, dan Mawar) DI KOTA BANDAR LAMPUNG
}

\author{
(Agribusiness System of Ornamental Flower Plants (Adenium, Orchids, and Rose) \\ in The City of Bandar Lampung)
}

Filipus Cahya Kusuma Putra, Yaktiworo Indriani, Maya Riantini

Jurusan Agribisnis, Fakultas Pertanian, Universitas Lampung, Jl. Prof. Dr. Soemantri Brodjonegoro No. 1

Bandar Lampung 35145, e-mail: yaktiworo.indriani@fp.unila.ac.id

\begin{abstract}
This study aims to analyze the process of procuring production facilities in accordance with the right six (on time, place, quality, quantity, type, and price), farm performance, the marketing efficiency of the agribusiness system, and the supporting institutions for ornamental flower agribusiness systems at Lampung. This study uses a survey method conducted in the city of Bandar Lampung, namely in Gunung Terang, Gunung Agung and in the Way Halim Permai. Sampling in this study was sixteen respondents taken using a quota sampling technique. Data collection was carried out in September - October 2019. The results showed that the procurement of production facilities of ornamental flower plant farming had fulfilled the right six. Ornamental flower farming in Bandar Lampung is feasible to be cultivated because in farming it has an $R /$ $C$ ratio $>1$, that is, the $R / C$ over the total cost of 1.70 of adenium flowers, 2.00 of orchids, and 1.60 of roses. The three ornamental flower plants studied have a profit margin ratio of more than 1 which is 1.41 of the adenium flower, 1.80 of the orchid flower, and 1.81 of the rose flower, which means that the ornamental flower farmers in Bandar Lampung receives profits and no loss. Supporting institutions in the flower plant agribusiness system at the research location are financial institutions, namely banks as financing and borrowing funds, government policies, and transportation. All these supporting institutions are available but have not been used optimally by farmers.
\end{abstract}

Key words: agribusiness system, $R / C$, profit margin ratio

\section{PENDAHULUAN}

Sektor pertanian merupakan sektor yang mempunyai peranan penting dalam meningkatkan perkembangan ekonomi Indonesia. Pertanian adalah sumber mata pencaharian utama sebagian besar masyarakat Indonesia. Salah satu subsektor pertanian adalah tanaman hortikultura. Subsektor hortikultura terdiri dari tanaman sayuran, buahbuahan, florikultura serta tanaman obat-obatan.

Komoditas agribisnis florikultura terdiri dari bunga potong yaitu bunga yang dipotong dari tanaman induk dan dimanfaatkan sebagai rangkaian bunga, dan tanaman hias yang mencakup semua tumbuhan, baik berbentuk terna, merambat, semak, perdu, ataupun pohon, yang sengaja ditanam orang sebagai komponen taman, kebun rumah, penghias ruangan. Salah satu komoditas florikultura yang memiliki peluang usaha yang cukup menjanjikan untuk dikembangkan adalah tanaman hias. Bunga potong pun dapat dimasukkan sebagai tanaman hias. Tanaman hias merupakan tanaman yang mempunyai nilai keindahan baik karena bentuk, warna daun, tajuk maupun bunganya, sering digunakan sebagai penghias pekarangan atau ruangan di rumah-rumah atau gedung perkantoran (Gunawan 1998).

Prospek agribisnis tanaman hias di Bandar Lampung cukup menjanjikan, pengembangan tanaman hias yang besar akan membawa dampak peluang pasar yang baik bagi para pelaku bisnis tanaman hias. Beberapa segmentasi pasar tanaman hias yang cukup luas, seperti wedding organizer, pengelola hotel, kantor, universitas, dan sekolah, serta masyarakat umum lainnya yang menyelenggarakan hajatan tertentu.

Jenis tanaman hias yang diproduksi di Provinsi Lampung di antaranya jenis tanaman hias daun seperti lidah mertua, kuping gajah dan tanduk rusa, tanaman hias batang seperti palem bambu, bambu kuning, dan kaktus, serta tanaman hias bunga seperti, adenium, anggrek, dan mawar. Tanaman hias bunga di Bandar Lampung banyak diminati dan dicari oleh konsumen dan pedagang karena mempunyai bentuk dan warna yang indah, 
sehingga banyak digunakan untuk menghiasi ruangan dan taman, serta perawatannya yang lebih mudah dibandingkan dengan tanaman hias batang dan tanaman hias daun.

Berdasarkan prasurvei yang telah dilakukan, produksi yang belum optimal disebabkan oleh beberapa hal seperti karakterisktik petani yang berbeda-beda, kurangnya modal, kelangkaan saprodi pada musim tanam, serta perubahan cuaca yang cepat dan sulit untuk diprediksi. Jika musim kemarau sering terjadi kekeringan pada media tanaman hias karena penyiraman yang belum optimal. Ketika musim hujan dengan intensitas yang tinggi dapat menyebabkan tanaman hias rusak, serangan hama dan penyakit banyak terjadi.

Lembaga pemasaran yang terlibat juga akan mempengaruhi marjin pemasaran, semakin tinggi marjin pemasaran maka akan semakin kecil pula persentasi harga yang diterima oleh petani (Firdaus 2008). Petani juga masih menghadapi ketidakpastian harga jual, ketika terjadi panen yang bersamaan harga tanaman hias bunga sering mengalami penurunan (Fitriani 2017). Lembaga penunjang yang ada yaitu kelompok tani, koperasi, bank, kebijakan pemerintah, teknologi informasi dan komunikasi. Lembaga penunjang belum mampu mengumpulkan kekuatan petani dalam penetapan harga, selain itu juga masih menghadapi keterbatasan kelembagaan terutama dalam masalah modal, pengadaan sarana produksi, penggunaan teknologi serta pemasaran.

Tujuan penelitian ini adalah mengetahui pengadaan sarana produksi, serta menganalisis kinerja usahatani, pemasaran dan lembaga penunjang sistem agribisnis tanaman hias bunga.

\section{METODE PENELITIAN}

Penelitian ini menggunakan metode survei. Pengambilan sampel petani dalam penelitian ini menggunakan teknik quota sampling dengan mengambil jumlah sampel sebanyak jumlah yang telah ditentukan oleh penulis karena jumlah petani yang terbatas. Sampel pedagang diambil dengan teknik snowball sampling yaitu pemilihan sampel dengan terlebih dahulu menetapkan satu informasi kunci kemudian sampel berikutnya tergantung kepada informasi yang diberikan tersebut. (Margono 2004). Jumlah sampel yang diperoleh 16 petani yaitu 4 petani bunga adenium, 7 petani bunga anggrek, dan 5 petani bunga mawar serta 9 lembaga pemasaran tanaman hias bunga yang ada di Bandar Lampung.
Data primer diperoleh melalui wawancara secara langsung menggunakan kuesioner. Data sekunder diperoleh dari studi literature, laporan-laporan, publikasi dan pustaka yang berhubungan dengan tujuan penelitian.

Berikut adalah alat analisis yang digunakan dalam penelitian sistem agribisnis tanaman hias bunga : Analisis yang digunakan dalam pengadaan sarana produksi adalah analisis deskriptif kualitatif dan kualitatif. Analisis ini dilakukan dengan melakukan pengamatan mengenai keadaaan lokasi penelitian meliputi lahan, pengadaan bibit, pengadaan, pestisida, tenaga kerja, dan alat produksi, melalui 6T yaitu tepat jenis, tepat harga, tepat waktu, tepat tempat, tepat kualitas dan tepat kuantitas.

Tingkat ketepatan dalam 6T penyediaan sarana produksi usahatani tanaman hias bunga di Kota Bandar Lampung 6T dihitung dengan rumus :

Tingkat ketepatan $=\frac{\text { Bobot nila diperoleh }}{\text { Bobot nilai maksimum }} \times 100 \ldots \ldots$ (1)

Tingkat ketepatan digolongkan menjadi empat yang mengacu pada kriteria analisis deskriptif dengan persentase 75 persen-100 persen berada pada kriteria sangat baik, 50 persen-75 persen berada pada kriteria baik, 25 persen-50 persen berada pada kriteria cukup baik, dan 1 persen-25 persen berada pada kriteria kurang baik (Ridwan 2004).

Pendapatan usahatani tanaman hias bunga dikaji berdasarkan dua indikator yaitu pendapatan dan rasio R/C. Pendapatan didapatkan dari selisih antara penerimaan dan biaya yang dengan menggunakan rumus (Shinta 2011).

$\pi=\mathrm{TR}-\mathrm{TC}$

Keterangan :

$\pi=$ Pendapatan usahatani

$\mathrm{TR}=$ Penerimaan usahatani

$\mathrm{TC}=$ Biaya usahatani

Total penerimaan usahatani tanaman hias bunga diperoleh dari jumlah produksi dikali dengan harga jual, menggunakan rumus (Shinta 2011).

$\mathrm{TR}=\mathrm{Y} . \mathrm{Py}$

Keterangan :

$\mathrm{TR}=$ Total Revenue atau penerimaan total

$\mathrm{Y}=$ Output atau produksi yang diperoleh 
Py $=$ Price atau harga output

Total biaya diperoleh dari seluruh biaya yang dikeluarkan dalam usahatani rumus (Shinta 2011).

$\mathrm{TC}=\mathrm{FC}+\mathrm{VC}$

Keterangan:

$\mathrm{TC}=$ Total Cost atau biaya total

$\mathrm{FC}=$ Fixed Cost atau biaya tetap

$\mathrm{VC}=$ Variable Cost atau biaya variabel

Rasio R/C merupakan perbandingan antara penerimaan total usahatani dengan biaya total usahatani selama proses produksi. (Shinta 2011).

$\mathrm{R} / \mathrm{C}=\mathrm{TR} / \mathrm{TC}$

Keterangan:

$\mathrm{R} / \mathrm{C}=$ Nisbah antara penerimaan dengan biaya

$\mathrm{TR}=$ Total Revenue atau penerimaan total

$\mathrm{TC}=$ Total Cost (biaya total)

Analisis marjin digunakan untuk mengetahui pemasaran produk mulai dari petani hingga ke konsumen, dapat menggunakan rumus (Hasyim 2012).

$\mathrm{Mji}=$ Psi-Pbi atau

ji $=$ bti $+\pi \mathrm{i}$ atau

$\pi \mathrm{i}=$ Mji-bti.

Penyebaran marjin dapat dilihat berdasarkan persentase keuntungan terhadap biaya pemasaran Ratio Profit Margin pada masing - masing lembaga pemasaran, dapat menggunakan rumus (Hasyim 2012).

$\mathrm{RPM}=\frac{\pi \mathrm{i}}{\mathrm{bti}}$

Keterangan :

Mji $=$ Marjin pemasarantingkat ke-i

Psi = Harga penjualan lembaga pemasaran tingkat ke-i

Pbi = Harga pembelian lembaga pemasaran tingkat ke-i

bti = Biaya pemasaran lembaga pemasaran tingkat ke-i

$\pi \mathrm{i}=$ Keuntungan lembaga pemasaran tingkat ke-i

Menurut Hasyim (2012) nilai RPM yang relatif menyebar merata pada berbagai tingkat pemasaran adalah cerminan dari sistem pemasaran yang efesien. Jika selisih RPM antar lembaga pemasaran sama dengan nol, maka pemasaran tersebut efisien. Sebaliknya, jika selisih RPM lembaga pemasaran tidak sama dengan nol, maka sistem pemasaran tersebut tidak efisien.

Analisis lembaga penunjang menggunakan metode deskriptif kualitatif yang digunakan untuk mengetahui lembaga penunjang yang memiliki peran dalam agribisnis tanaman hias bunga di Bandar Lampung.

\section{HASIL DAN PEMBAHASAN}

\section{Karakteristik Responden}

Sebaran umur menurut kelompok umur tidak merata karena mayoritas petani dan pedagang tanaman hias bunga berada pada kelompok umur 45-57 tahun, tingkat pendidikan berada pada tingkat SMP, tanggungan keluarga 3-4 orang, serta pengalaman berusahatani 13-17 tahun. Berdasarkan hasil penelitian karakteristik responden akan mempengaruhi cara berusahatani seperti pengambilan keputusan dalam pemilihan dan perhitungan penggunaan sarana produksi.

\section{Pengadaan Sarana Produksi}

Tingkat ketepatan dalam penyediaan sarana produksi usahatani tanaman hias bunga berdasarkan 6T yaitu tepat jenis, tepat harga, tepat waktu, tepat tempat, tepat kualitas dan tepat kuantitas diperoleh :

Tingkat Ketepatan $=\frac{29}{30} \times 100 \%=96,70 \%$.

Hasil penelitian menunjukkan bahwa pengadaan sarana produksi tanaman hias bunga di Bandar Lampung berada pada kriteria sangat baik dengan persentase sebesar 95 persen -100 persen. Penelitian ini juga sesuai dengan penelitian yang dilakukan oleh Oktaviana et al. (2016), yakni tersedianya faktor dan sarana produksi dari segi kualitas, kuantitas, waktu dan biaya yang tepat.

\section{Produksi dan Pendapatan}

Produksi tanaman hias bunga merupakan jumlah hasil budidaya tanaman hias bunga yang diterima per usahatani yang telah dilakukan. Oleh karena itu luas lahan per pohon dan faktor produksi lainnya berpengaruh terhadap produksi yang dihasilkan petani yang kemudian akan berpengaruh terhadap penerimaan petani, peneriman petani dalam satu musim tanam didapat tiga kali penerimaan yaitu pada bulan pertama, bulan kedua 
Tabel 1. Rata-rata penerimaan, biaya, pendapatan dan rasio $\mathrm{R} / \mathrm{C}$ usahatani tanaman hias bunga.

\begin{tabular}{|c|c|c|c|c|}
\hline \multirow{2}{*}{ Uraian } & Satuan & Jumlah & Harga $(\mathrm{Rp})$ & Total Nilai (Rp) \\
\hline & \multicolumn{4}{|c|}{ Usahatani tanaman hias bunga adenium per 500 pohon } \\
\hline Produksi & pohon & 500,00 & $66.766,67$ & $33.383 .333,33$ \\
\hline Bibit & pohon & 500,00 & $4.875,00$ & $2.437 .500,00$ \\
\hline GDM Pupuk Cair Organik & liter & 28,89 & $30.000,00$ & $866.666,67$ \\
\hline Pupuk NPK Mutiara 16-16-16 & $\mathrm{kg}$ & 32,22 & $11.500,00$ & $370.555,56$ \\
\hline Pupuk Organik & $\mathrm{kg}$ & 266,67 & 500,00 & $133.333,33$ \\
\hline Pestisida & $\mathrm{Rp}$ & & & $109.722,22$ \\
\hline TKLK & $\mathrm{Rp}$ & & & $3.055 .555,56$ \\
\hline $\mathrm{PBB}$ & $\mathrm{Rp}$ & & & $43.333,33$ \\
\hline Total Biaya Tunai & & & & $7.016 .666,67$ \\
\hline Sewa Lahan & $\mathrm{Rp}$ & & & $988.888,89$ \\
\hline TKDK & $\mathrm{Rp}$ & & & $2.333 .333,33$ \\
\hline Penyusutan Alat & $\mathrm{Rp}$ & & & $1.840 .555,56$ \\
\hline Total Biaya Diperhitungkan & & & & $5.162 .777,78$ \\
\hline Total Biaya & & & & $12.179 .444,44$ \\
\hline Pendapatan Atas Biaya Tunai & & & & $26.366 .666,67$ \\
\hline Pendapatan Atas Biaya Total & & & & $21.203 .888,89$ \\
\hline $\mathrm{R} / \mathrm{C}$ Atas Biaya Tunai & & & & 4,76 \\
\hline \multirow[t]{2}{*}{ R/C Atas Biaya Total } & & & & 2,74 \\
\hline & \multicolumn{4}{|c|}{ Usahatani tanaman hias bunga anggrek per 500 pohon } \\
\hline Produksi & pohon & 500,00 & $72.713,64$ & $36.356 .818,18$ \\
\hline Bibit & pohon & 500,00 & $8.571,43$ & $4.285 .714,29$ \\
\hline GDM Pupuk Cair Organik & liter & 23,18 & $30.000,00$ & $695.467,19$ \\
\hline Pupuk NPK Mutiara 16-16-16 & $\mathrm{kg}$ & 26,82 & $11.500,00$ & $308.414,70$ \\
\hline Pupuk Organik & $\mathrm{kg}$ & 186,37 & 500,00 & $93.183,51$ \\
\hline Pestisida & $\mathrm{Rp}$ & & & $60.569,28$ \\
\hline TKLK & $\mathrm{Rp}$ & & & $1.500 .027,27$ \\
\hline PBB & $\mathrm{Rp}$ & & & $34.318,81$ \\
\hline Total Biaya Tunai & & & & $6.977 .695,05$ \\
\hline Sewa Lahan & $\mathrm{Rp}$ & & & $984.108,80$ \\
\hline TKDK & $\mathrm{Rp}$ & & & $1.522 .754,96$ \\
\hline Penyusutan Alat & $\mathrm{Rp}$ & & & $1.808 .623,79$ \\
\hline Total Biaya Diperhitungkan & & & & $4.315 .487,55$ \\
\hline Total Biaya & & & & $11.293 .182,60$ \\
\hline Pendapatan Atas Biaya Tunai & & & & $29.379 .123,13$ \\
\hline Pendapatan Atas Biaya Total & & & & $25.063 .635,58$ \\
\hline $\mathrm{R} / \mathrm{C}$ Atas Biaya Tunai & & & & 5,21 \\
\hline \multirow[t]{2}{*}{ R/C Atas Biaya Total } & \multirow{2}{*}{\multicolumn{4}{|c|}{ Usahatani tanaman hias mawar per 500 pohon }} \\
\hline & & & & \\
\hline Produksi & pohon & 500,00 & $57.516,67$ & $28.758 .333,33$ \\
\hline Bibit & pohon & 500,00 & $2.800,00$ & $1.400 .000,00$ \\
\hline GDM Pupuk Cair Organik & liter & 28,33 & $30.000,00$ & $850.000,00$ \\
\hline Pupuk NPK Mutiara 16-16-16 & $\mathrm{kg}$ & 30,83 & $11.500,00$ & $354.583,33$ \\
\hline Pupuk Organik & $\mathrm{kg}$ & 233,33 & 500,00 & $116.666,67$ \\
\hline Pestisida & $\mathrm{Rp}$ & & & $99.583,33$ \\
\hline TKLK & $\mathrm{Rp}$ & & & $3.333 .333,33$ \\
\hline $\mathrm{PBB}$ & $\mathrm{Rp}$ & & & $38.750,00$ \\
\hline Total Biaya Tunai & & & & $6.192 .916,67$ \\
\hline Sewa Lahan & $\mathrm{Rp}$ & & & $979.166,67$ \\
\hline TKDK & $\mathrm{Rp}$ & & & $2.833 .333,33$ \\
\hline Penyusutan Alat & $\mathrm{Rp}$ & & & $1.852 .083,33$ \\
\hline Total Biaya Diperhitungkan & & & & $5.664 .583,33$ \\
\hline Total Biaya & & & & $11.857 .500,00$ \\
\hline Pendapatan Atas Biaya Tunai & & & & $22.565 .416,67$ \\
\hline Pendapatan Atas Biaya Total & & & & $16.900 .833,33$ \\
\hline $\mathrm{R} / \mathrm{C}$ Atas Biaya Tunai & & & & 4,64 \\
\hline R/C Atas Biaya Total & & & & 2,43 \\
\hline
\end{tabular}

dan bulan ketiga. Berdasarkan perhitungan pendapatan yang telah diperoleh, dapat disimpulkan bahwa usahatani tanaman hias bunga adenium, anggrek dan mawar menguntungkan.
Hasil ini diperkuat dengan nilai $\mathrm{R} / \mathrm{C}$ atas biaya tunai sebesar 4,76 dan R/C atas biaya total sebesar 2,74 untuk bunga adenium, nilai $\mathrm{R} / \mathrm{C}$ atas biaya tunai adalah 5,21 dan $\mathrm{R} / \mathrm{C}$ atas biaya total adalah 3,22 untuk bunga anggrek, dan bunga mawar R/C 
atas biaya tunai adalah 4,64 dan $\mathrm{R} / \mathrm{C}$ atas biaya total adalah 2,63. Nilai $\mathrm{R} / \mathrm{C}$ ini menunjukkan bahwa usahatani tanaman hias bunga di Bandar Lampung menguntungkan karena $\mathrm{R} / \mathrm{C}>1$. Hasil penelitian menunjukkan bahwa tanaman hias bunga, yang memiliki $\mathrm{R} / \mathrm{C}$ terbesar adalah tanaman hias bunga anggrek dengan $\mathrm{R} / \mathrm{C}$ atas biaya tunai 5,21 dan $\mathrm{R} / \mathrm{C}$ atas biaya total 3,22. Tanaman hias bunga anggrek mempunyai daya tarik tersendiri dengan bunganya yang indah dan cantik sehingga banyak diminati oleh konsumen walaupun harganya relatif mahal.

Hasil penelitian ini tidak jauh berbeda dengan hasil penelitian Dony (2018) tentang analisis usahatani anggrek di Kecamatan Gunung Sindur Kabupaten Bogor. Hasil penelitian menunjukkan tanaman anggrek memiliki potensi besar untuk dibudidayakan terutama di Jawa Barat tepatnya di Kecamatan Gunung Sindur Kabupaten Bogor, menghasilkan R/C pada skala 2 sebesar Rp3,06 dan Rp1,91 pada skala 2, artinya usaha tersebut layak untuk dijalankan.

\section{Efisiensi Pemasaran}

Struktur pasar merupakan karakteristik yang dapat menentukan hubungan antara pedagang dan pembeli, antara penjual satu dengan lainnya serta penjual potensial (Hasyim, 2012). Lembaga pemasaran tanaman hias bunga terdiri dari petani yang berperan sebagai produsen, pedagang pengumpul (skala kecil dan besar) dan konsumen. Bila dilihat dari banyaknya jumlah pembeli dan penjual yang ada pada lokasi penelitian, maka jenis pemasaran berada pada struktur oligopsoni.

Petani memiliki kebebasan dalam menjual hasil panen dan tidak ada pembagian wilayah petani kepada siapa dan kemana tanaman hias bunga akan dijual dan sesuai dengan penelitian Ramadhani, et al. (2014), hal tersebut dikarenakan tidak adanya kontrak dalam melakukan pemasaran sehingga petani bebas dalam melakukan penjualan. Mekanisme penjualan yang terjadi adalah langganan terbiasa menjual tanaman hias bunga kepada pedagang, tetapi tidak memiliki kontrak.

Menurut Hasyim (2012) marjin pemasaran memiliki peran yang penting dalam penentuan besar atau kecilnya pendapatan petani karena adanya pengaruh secara langsung terhadap pembentukan harga ditingkat petani produsen. Komponen biaya pemasaran tanaman hias bunga terdiri dari biaya transportasi, biaya sopir dan tenaga kerja.
Saluran pemasaran tanaman hias bunga terdiri dari dua saluran pemasaran yaitu petani $\rightarrow$ pedagang $\rightarrow$ konsumen dan petani $\rightarrow$ konsumen. Harga jual petani tanaman hias bunga adenium ke pedagang pengumpul adalah Rp65.000 dan harga jual dari pedagang pengumpul ke konsumen adalah Rp79.000. Rasio profit marjin yang didapatkan dari hasil penelitian sebesar Rp1,41 yang memiliki arti bahwa setiap Rp1,00 yang dikeluarkan maka akan mendapatkan keuntungan sebesar Rp1,41.

Harga jual petani tanaman hias bunga anggrek ke pedagang adalah Rp70.000 dan harga jual dari petani ke konsumen adalah Rp85.000. Rasio profit marjin yang didapatkan dari hasil penelitian sebesar Rp1,80 yang memiliki arti bahwa setiap Rp1,00 yang dikeluarkan maka akan mendapatkan keuntungan sebesar Rp1,80.

Harga jual petani tanaman hias bunga mawar ke pedagang pengumpul adalah Rp55.000 dan harga jual dari pedagang pengumpul ke konsumen adalah Rp68.667. Rasio profit marjin yang didapatkan dari hasil penelitian sebesar Rp1,81 yang memiliki arti bahwa setiap Rp1,00 yang dikeluarkan maka akan mendapatkan keuntungan sebesar Rp1,81. Harga menjadi salah satu faktor dalam penerimaan keuntungan, setiap besarnya marjin keuntungan yang didapat akan mempengaruhi efisiensi pemasaran (Widiastuti dan Harisudin 2013). Analisis marjin pemasaran tanaman hias bunga dapat dilihat pada Tabel 2.

Harga menjadi salah satu faktor dalam penerimaan keuntungan, setiap besarnya marjin keuntungan yang didapat akan mempengaruhi efisiensi pemasaran (Widiastuti dan Harisudin 2013). Hasil penelitian Ramadhani et al. (2014) juga menyatakan bahwa efisiensi pemasaran sangat dipengaruhi tingkat harga di produsen dan konsumen serta panjang saluran pemasaran. Apabila harga tingkat produsen semakin dekat dengan tingkat harga konsumen maka pemasaran yang dilakukan cenderung telah efisien.

\section{Lembaga Penunjang}

terdapat lembaga keuangan nonformal antara lain pedagang pengumpul dan pedagang sarana produksi / toko pertanian. Adapun peranan pemilik toko pertanian adalah dapat memberikan bantuan dahulu berupa sarana produksi dan dapat dibayar saat panen tetapi dengan harga yang sedikit lebih 
Tabel 2. Analisis margin pemasaran tanaman hias bunga

\begin{tabular}{|c|c|c|c|c|}
\hline No. & Uraian & $\begin{array}{c}\text { Margin } \\
(\%)\end{array}$ & $\begin{array}{c}\text { Pangsa } \\
(\%)\end{array}$ & $\begin{array}{c}\text { RPM } \\
(\%)\end{array}$ \\
\hline \multirow{12}{*}{$\begin{array}{l}1 . \\
2 .\end{array}$} & & Adenium & & \multirow{14}{*}{1,80} \\
\hline & Harga jual & & & \\
\hline & Petani & $70.000,00$ & 82,35 & \\
\hline & Pedagang & & & \\
\hline & a. Harga beli & $70.000,00$ & 82,35 & \\
\hline & b. Biaya total & $5.358,33$ & 6,30 & \\
\hline & Transportasi & $2.191,67$ & 2,58 & \\
\hline & Sopir & $1.583,33$ & 1,86 & \\
\hline & Tenaga Kerja & $1.583,33$ & 1,86 & \\
\hline & c. Margin & $15.000,00$ & 17,65 & \\
\hline & d. Keuntungan & $9.641,67$ & 11,34 & \\
\hline & e. Harga jual & $85.000,00$ & & \\
\hline \multirow[t]{2}{*}{3.} & Konsumen & & & \\
\hline & Harga Beli & $85.000,00$ & & \\
\hline \multicolumn{5}{|c|}{ Anggrek } \\
\hline \multirow{11}{*}{$\begin{array}{l}1 . \\
2 .\end{array}$} & Harga jual & & & \multirow{13}{*}{1,80} \\
\hline & Petani & $70.000,00$ & 82,35 & \\
\hline & Pedagang & & & \\
\hline & a. Harga beli & $70.000,00$ & 82,35 & \\
\hline & b. Biaya total & $5.358,33$ & 6,30 & \\
\hline & Transportasi & $2.191,67$ & 2,58 & \\
\hline & Sopir & $1.583,33$ & 1,86 & \\
\hline & Tenaga Kerja & $1.583,33$ & 1,86 & \\
\hline & c. Margin & $15.000,00$ & 17,65 & \\
\hline & d. Keuntungan & $9.641,67$ & 11,34 & \\
\hline & e. Harga jual & $85.000,00$ & & \\
\hline \multirow[t]{2}{*}{3.} & Konsumen & & & \\
\hline & Harga Beli & $85.000,00$ & & \\
\hline \multicolumn{5}{|c|}{ Mawar } \\
\hline \multirow{3}{*}{1.} & Harga jual & & & \multirow{14}{*}{1,81} \\
\hline & Petani & $55.000,00$ & 80,10 & \\
\hline & Pedagang & & & \\
\hline \multirow[t]{9}{*}{2.} & Pengumpul & & & \\
\hline & a. Harga beli & $55.000,00$ & 80,10 & \\
\hline & b. Biaya total & $4.866,67$ & 7,09 & \\
\hline & Transportasi & $2.227,78$ & 3,24 & \\
\hline & Sopir & $1.083,33$ & 1,58 & \\
\hline & Tenaga Kerja & $1.555,56$ & 2,27 & \\
\hline & c. Margin & $13.666,67$ & 19,90 & \\
\hline & d. Keuntungan & $8.800,00$ & 12,82 & \\
\hline & e. Harga jual & $68.666,67$ & & \\
\hline \multirow[t]{2}{*}{3.} & Konsumen & & & \\
\hline & Harga Beli & $68.666,67$ & & \\
\hline
\end{tabular}

mahal dibandingkan dengan pembelian secara tunai. Pupuk kandang merupakan sarana produksi yang sering dihutang petani ke pemilik toko karena jumlah kebutuhan pupuk cukup besar. Lembaga keuangan ini sangat bermanfaat bagi petani apabila petani telah memanfaatkannya secara optimal.

Pemerintah telah memberikan bibit yang sudah bersertifikat yang berada dalam naungan Balai Penelitian Tanaman Hias (BPTH) dan Direktorat Jendral Hortikultura, sehingga petani juga merasa lebih aman dalam melakukan usahatani, penggunaan bibit yang berkualitas akan memberikan dampak yang baik bagi usahatani.
Pemerintah pusat memiliki peran yang penting dalam kelancaran agribisnis tanaman hias bunga.

Transportasi merupakan hal yang penting dalam kelancaran sistem agribisnis, dalam melakukan kegiatan pemasaran tanaman hias bunga, kendaraan yang digunakan dalam pengangkutan tanaman hias bunga biasanya adalah mobil pick up. Keseharian kendaraan yang sering dipakai petani adalah motor, sarana transportasi lain yang cukup penting adalah jalan yang baik dan memadai sehingga memudahkan dalam kegiatan. Akses jalan yang berada di lokasi penelitiaan sudah diaspal, sehingga mempermudah dalam sistem agribisnis tanaman hias bunga, terutama dalam pengangkutan yang dilakukan oleh pedagang pengumpul dan petani.

\section{KESIMPULAN}

Pengadaan sarana produksi agribisnis tanaman hias bunga berdasarkan kriteria $6 \mathrm{~T}$ tepat jenis, tepat harga, tepat waktu, tepat tempat, tepat kualitas dan tepat kuantitas, telah sesuai pengadaan sarana produksi yang meliputi bibit, pupuk, pestisida, tenaga kerja dan alat pertanian, secara umum kuantitas penggunaan sarana produksi sudah tepat kuantitas karena sarana produksi yang digunakan sesuai dengan aturan penngunan tidak berlebihan ataupun kurang serta saprodi tanaman hias bunga tersedia sebelum masa tanam.

Kinerja usahatani tanaman hias bunga di Bandar Lampung telah baik yaitu menguntungkan baik itu tanaman hias bunga adenium, anggrek, dan mawar yang dapat dilihat dari segi pendapatan. Usahatani tanaman hias bunga menguntungkan karena nilai $\mathrm{R} / \mathrm{C}$ atas biaya tunai dan biaya total lebih dari satu dengan $\mathrm{R} / \mathrm{C}$ terbesar adalah tanaman hias bunga anggrek dengan $\mathrm{R} / \mathrm{C}$ atas biaya tunai 3,30 dan $\mathrm{R} / \mathrm{C}$ atas biaya total 2,05 .

Sistem pemasaran tanaman hias bunga di Bandar Lampung terdiri dari petani, pedagang pengumpul atau florist, dan konsumen. Rantai pemasaran tanaman hias bunga relatif pendek dan hal ini baik bagi petani, karena apabila semakin panjang rantai pemasaran maka marjin yang akan diterima petani jadi semakin kecil.

Rantai pemasaran tanaman hias bunga memengaruhi marjin pemasaran. Marjin pemasaran merupakan salah satu indikator efisiensi pemasaran. Pada ketiga tanaman hias bunga yang diteliti mempunyai rasio profit margin lebih dari 1 yang berarti petani tanaman hias bunga di Bandar 
Lampung memperoleh keuntungan dan tidak mengalami kerugian.

Lembaga penunjang pada sistem agribisnis tanaman hias bunga pada lokasi penelitian adalah lembaga keuangan yaitu Bank Rakyat Indonesia (BRI), sebagai pembiayaan dan peminjaman dana, kebijakan pemeritah, dan transportasi.

\section{DAFTAR PUSTAKA}

Andri BA, Willem JF, dan Alfa T. 2015. Potensi pengembangan agribisnis bunga anggrek di Kota Batu Jawa Timur. Jurnal LPPM. Vol 2 (1): 19-30. https://www.neliti.com/id/publications/10867 1/potensi-pengembangan-agribisnis-bungaanggrek-di-kota-batu-jawa-timur\#id-sectioncontent. [29 Agustus 2019].

Dinata AS, Lestari DAH, dan Yanfika H. 2014. Pendapatan petani jagung anggota dan nonanggota koperasi tanimakmur Desa Natar Kabupaten Lampung Selatan. Jurnal Ilmu Ilmu Agribisnis. Vol 2 (3): 206-213. http://jurnal.fp.unila.ac.id/index.php/JIA/articl e/view/802. [5 Agustus 2019].

Dony AOP. 2018. Analisis usahatani anggrek di Kecamatan Gunung Sindur Kabupaten Bogor. Jurnal Sosial Ekonomi Pembangunan, Vol 7 (2): 48-62. http:// repository.ipb.ac.id. [3 Maret 2020].

Firdaus M. 2008. Manajemen Agribisnis. Bumi Aksara. Jakarta.

Gunawan W. 1998. Budidaya Tanaman Hias. Penebar Swadaya. Jakarta
Hasyim AI. 2012. Tataniaga Pertanian. Universitas Lampung. Lampung.

Margono M. 2004. Teknik dan Metode Pengambilan Data. Edisi Kedua. PT Penerbit IPB Press. Food and Agribusiness

Oktaviana E, Lestrai DAH, dan Indriani Y. 2016. Sistem agribisnis ayam kalkun di Desa Sukoharjo Kabupaten Pringsewu Provinsi Lampung. Jurnal Ilmu - Ilmu Agribisnis. Vol $4 \quad$ (3): 262-268. http://jurnal.fp.unila.ac.id/index.php/JIA/articl e/view/1500/1354. [5Agustus 2019].

Ramadhani DK, Rahayu ES, dan Setyowati. 2014. Analisis efisiensi pemasaran jagung (Zea mays) di Kabupaten Grobogan (Studi Kasus di Kecamatan Geyer). Jurnal Ilmu - Ilmu Agribisnis. $\quad$ Vol 4 (3): 262-268. http://jurnal.fp.unila.ac.id/index.php/JIA/articl e/view/1500/1354https://eprints.unsac.id/1242 8/. [2 Agustus 2018].

Ridwan. 2014. Pengadaan Sarana Produksi dalam Agribisnis..Bumi Aksara. Jakarta.

Shinta A. 2011. Ilmu Usahatani. UB Press. Malang. http://shinta.lecture.ub.ac.id/files /2012/11/Ilmu-Usaha-Tani.pdf. [5 Agustus 2019].

Widiastuti N dan Harisudin M. 2013. Saluran dan marjin pemasaran jagung di Kabupaten Grobogan. SEPA. Vol 9 (2): 231 - 240. https://eprints.uns.ac.id/1481 /1/Saluran-danMarjin-Pemasaran https://eprints.uns.ac.id/1481/1/Saluran-danMarjin-Pemasaran-Jagung.pdfJagung.pdf . [5 Agustus 2019]. 